\title{
Integrating ICT in Teaching and Learning at Sultan Qaboos University: Current Status and Future Recommendations
}

\author{
Abdelrahman Mohamed Ahmed
}

\begin{abstract}
The present study investigated the current status of integrating ICT into teaching and learning at Sultan Qaboos University (SQU). A sample of 220 faculty members from six different colleges and four administrators from the Center of Educational Technology (CET) and the Center for Information Systems (CIS) at SQU in Oman were chosen, and quantitative qualitative design using a semi-structured questionnaire, interviews and checklists was employed. The findings show that SQU had a high availability of ICT infrastructure in terms of hardware, software and support services, as well as adequate computer labs for educational purposes. However, the results also indicated that, although SQU provided a series of professional development workshops related to using ICT in teaching, few faculty members were interested. Furthermore, the finding indicated that, the degree of ICT integration into teaching at SQU was at a medium level. Given the importance of ICT integration in teaching and learning, it is recommended that SQU should recognise and acknowledge the faculty members' role in ICT integration. Therefore, it should provide ways to support faculty members in developing their ICT skills and knowledge and increasing capability in performing their role.
\end{abstract}

Index Terms-Information and communication technology (ICT), integration, professional development.

\section{INTRODUCTION}

Researchers have identified several factors influencing the adoption and integration of ICT into teaching. Teachers' integration of ICT into teaching is influenced by organisational factors, attitudes towards technology and others [1]-[4]. Neyland (2011) identified both macro factors, such as institutional support, and micro factors, such as teacher capability, as influencing the use of online learning in high schools in Sydney [5]. Prior to integrating ICT tools, it is crucial to consider several improvements to the infrastructure of Higher Educational Institutions (HEIs), including the funding of ICTs, sufficient training for ICT users, adequate policymaking, careful planning, the tailoring of teaching processes in accordance with available technologies and a systematic plan to integrate ICTs into HEIs [6], [7]. Turugare \& Rudhumbu, (2020) identified also some factors that serve as major opportunities for enabling effective technology integration, which include opportunities for individualised staff development, availability of technical support, availability of a fair supply of infrastructure and continuous professional development [8]. These factors are required to

Manuscript received April 17, 2020; revised October 15, 2020.

Abdelrahman Mohamed Ahmed Elhaj is with the Sultan Qaboos University, Oman (e-mail: abdoelhaj@squ.edu.om). ensure the usefulness of ICT tools. Mbodila, Jones and Muhandji (2013) further added that the integration of ICTs requires solving issues related to infrastructure: namely, access, equity, management, efficiency, pedagogy, quality, research and innovation [6]. In addition, Rubang-Doctor, Pa-alisbo \& Allanic (2019) argue that, technological characteristics influence the adoption and integration of ICT in teaching [9]. A review of the research reveals that ICT utilisation improves the quality of both teaching and learning in HEIs [10], [11]. Yet, inappropriate infrastructure can cause several challenges that impact the quality of ICT in education [6], [11].

Several studies have identified teacher training as a major concern in ICT integration. It has been argued that educating teachers to use ICTs is a necessary step that comes before providing technology and infrastructure [6], [7], [10]-[15]. Educators who are not aware of ICT use cannot be expected to integrate it into their teaching, although ICTs are required to cope with the rapid development of teaching practice. Mafuraga and Moremi (2017) suggested that instructors should receive continuous in-service training in appropriate ICT usage to cope with new technologies [16]. Turugare \& Rudhumbu, (2020) in their study found that limited financial resources, limited investment in new technology, lack of systematic and sustainable approaches for staff development were some of the major challenges faced to support effective technology integration [8].

The integration of ICTs provides countless opportunities and possibilities for learners in both higher education and general education. ICTs are significant tools for empowering knowledge and information; therefore, there is a strong need for policymakers and teachers to be aware of how technologies interact and work to use them effectively. It is not the technology that supports its integration, but the contextualised needs of teaching and learning in the educational curriculum [6].

Using ICTs is considered a condition for preparing learners for the future and meeting the technological advances of the 21 st century. Moreover, ICTs positively change how activities are prepared and introduced in teaching and learning, which can significantly change overall academic performance [6], [12], [15], [16]

The findings of this study may help policymakers and instructional developers recognise some of the factors affecting how faculty members integrate technology into their teaching. Given these concerns, the present research seeks to answer the following research questions:

1) To what extent is ICT (infrastructure, support services and resources) available at SQU?

2) What professional development programmes are 
provided for faculty members to integrate ICT in teaching?

3) To what extent are faculty members integrating ICT inside and outside the classroom?

4) Are there any differences in ICT integration according to college, gender, experience, or rank?

\section{Methodology}

This project used a quantitative-qualitative design. A semi-structured questionnaire, interviews and checklist were used to collect the relevant data.

\section{A. The Purpose of the Study}

The aim of this study is to explore the current status of using ICT in teaching and learning at SQU. More specifically, the study investigated the availability of ICT tools at SQU and the degree of technology integration at SQU. It also examined differences in technology integration according to college, gender, experience and rank.

\section{B. Significance of the Study}

Tis study investigated the integration of ICT at SQU in an attempt to provide useful information for further research into integrating ICT at SQU and for policymakers at the Ministry of Higher Education in Oman. The results may also provide valuable data that could help policy makers at SQU assess faculty members' current use of ICT in teaching and learning and may provide a baseline for future directions and continuous improvement.

\section{Subject of the Study}

The sample of this study consisted of 220 faculty members selected from six colleges at SQU. The faculty members were chosen randomly from the SQU colleges. Table I shows the demographic information of the study sample.

TABLE I: DEMOGRAPHIC INFORMATION OF THE STUDY SAMPLE

\begin{tabular}{|c|c|c|c|c|c|c|c|c|c|c|}
\hline \multirow{2}{*}{ 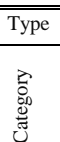 } & \multicolumn{2}{|c|}{ College } & \multicolumn{2}{|c|}{ Gender } & \multicolumn{3}{|c|}{ Experience } & \multicolumn{3}{|c|}{ Rank } \\
\hline & 吾 & $\begin{array}{l}: \\
\frac{\tilde{\Xi}}{\tilde{N}} \\
\tilde{n}\end{array}$ & $\frac{\frac{\omega}{\sigma}}{\Sigma}$ & 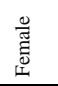 & প్ల & $\begin{array}{l}0 \\
\text { in } \\
\text { on }\end{array}$ & in & 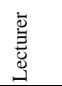 & 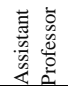 & 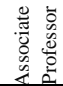 \\
\hline $\mathrm{N}$ & 107 & 113 & 179 & 41 & 12 & 135 & 73 & 20 & 125 & 56 \\
\hline Mean & 3.91 & 4.20 & 4.03 & 4.20 & 4.19 & 4.13 & 3.91 & 4.10 & 4.14 & 3.93 \\
\hline SD & .5751 & 5601 & .5963 & 5088 & .4760 & .6058 & .5349 & .4408 & .6205 & .5342 \\
\hline
\end{tabular}

In addition, four administrative staff from the Centre of Educational Technology (CET) and the Center for Information Systems (CIS) at SQU in were chosen to participate in this study.

\section{Instruments of the Study}

The data collection was conducted using three instruments: questionnaires and interviews with the faculty members and checklists with the administrators from CIS and CET.

\section{1) Questionnaire}

The questionnaire initially consisted of four categories: the availability of ICT infrastructure, professional development programmes on ICT use provided to faculty members and faculty members' use of ICT inside and outside the classroom. The questionnaire consisted of 60 statements; however, it was validated and modified in light of the referees' comments to include 51 statements in its final format. The reliability of the instrument was measured using Cronbach's alpha and the Statistical Package for Social Sciences version 23 (SPSS-23) and was found to be 0.88 .

\section{2) Checklist}

The Checklist consisted of 11 statements examining the number of labs, their types and the total numbers of computers per college; the ICT infrastructure/facilities utilised; and the total number of the computer technicians and instructional developers in each college. The Checklist was given to a panel of faculty members for face validation. They reviewed the instrument and gave suggestions, which the researchers used to revise the instrument.

\section{3) Interviews}

The interviews were conducted with four administrators from the CET and CIS centre and five faculty members from three colleges. The interviews with the faculty members concerned the types of ICT tools used in teaching by faculty members, the ways they integrated ICT tools in their teaching and the barriers impeding ICT integration in teaching. The interviews with the CET and CIS staff concerned information related to the main purpose of the CET and CIS, the types of support provided to faculty members by the CET or CIS, the total number of Moodle courses running at SQU, etc.

\section{E. Research Procedures}

This research project began in September 2017 with the literature review. An extensive ICT survey was conducted, and the instruments were compiled largely using items drawn from ICT surveys done by the researcher [17]. The instruments were reviewed and translated from English to Arabic. The researchers received a permission letter from SQU to conduct the study at a sample of colleges within the university. The questionnaires were piloted in two colleges in September 2018 to ascertain participants' level of difficulty completing them. The results of the pilot phase, which ran from November to December 2018, were used following comments by referees for face validation and other researchers in the field to form the final versions of the gestionnaires. In January 2019, the questionnaires were diministered to the sample of colleges, and the data ergllection took place from January to the end of February 25419.

The interviews were conducted with four administrators from the CET and CIS centres and five faculty members from three colleges. Each interview lasted about 30 minutes.

\section{RESUlTS}

\section{A. To What Extent Is ICT (Infrastructure, Support Services and Resources) Available at SQU?}

To answer this question, the researchers calculated the frequencies, percentages and means of the data regarding the availability of ICT infrastructure (hardware, software, Internet, support services and resources) at SQU's colleges and centres. Checklists and interviews were used to collect these data from the CIS and CET.

\section{1) ICT infrastructure (hardware, software and facilities)}

One basic indicator of SQU's ICT infrastructure 
availability is the number of computers and computer labs available to students and/or instructors for teaching and learning purposes. The checklist presented to the CIS staff and the technicians in the colleges asked respondents to specify the number of computer labs (specialised or free access) and computers (desktops, laptops and tablets) available to students in the labs and classrooms.

TABLE II: COMPUTERS AND COMPUTER LABS AVAILABLE AT SQU

\begin{tabular}{|c|c|c|c|c|c|c|c|}
\hline \multirow[t]{2}{*}{ No. } & \multirow[t]{2}{*}{ 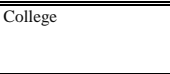 } & \multicolumn{3}{|c|}{ N Number of labs/types } & \multicolumn{2}{|c|}{ N Number of computers } & \multirow[b]{2}{*}{ Tablets } \\
\hline & & $\begin{array}{l}\text { Specialised } \\
\text { labs }\end{array}$ & $\begin{array}{l}\text { Free } \\
\text { labs }\end{array}$ & Total & $\begin{array}{l}\text { Desktop } \\
\text { computers }\end{array}$ & $\begin{array}{l}\text { Laptop } \\
\text { computers }\end{array}$ & \\
\hline 1 & Education & 9 & 4 & 13 & 345 & 68 & 100 \\
\hline 2 & Science & 37 & 1 & 38 & .... & 0 & 0 \\
\hline 3 & Engineering & 17 & 0 & 17 & 600 & 6 & 0 \\
\hline 4 & $\begin{array}{l}\text { Medicine \& Health } \\
\text { Science }\end{array}$ & 3 & 1 & 4 & 590 & 71 & 0 \\
\hline 5 & $\begin{array}{l}\text { Arts and Social } \\
\text { Sciences }\end{array}$ & 7 & 4 & 11 & 276 & 221 & 0 \\
\hline 6 & $\begin{array}{l}\text { Economics and } \\
\text { Political Science }\end{array}$ & 7 & 0 & 7 & 195 & 0 & 0 \\
\hline 7 & Law & 0 & 0 & 0 & 45 & 0 & 0 \\
\hline 8 & Nursing & 1 & 2 & 3 & 133 & 12 & - \\
\hline 9 & $\begin{array}{l}\text { Agricultural and } \\
\text { Marine Sciences }\end{array}$ & 2 & 1 & 3 & 215 & 8 & 0 \\
\hline 10 & $\begin{array}{l}\text { Center for Preparatory } \\
\text { Studies (CPS) } \\
\text { Centre for }\end{array}$ & 1 & 6 & 7 & 487 & 9 & NA \\
\hline 11 & $\begin{array}{l}\text { Information Systems } \\
\text { (CIS) }\end{array}$ & 8 & 1 & 9 & 529 & & \\
\hline Total & & 58 & 39 & 97 & 3415 & 395 & 100 \\
\hline
\end{tabular}

As indicated in Table II, SQU had 97 computer labs, including $58(59.8 \%)$ specialised labs and 39 (40.2\%) free access labs for students. The table also indicates that SQU had 3910 computers, including 3415 (87.3\%) desktop computers, $395(10.1 \%)$ laptop computers and approximately $100(2.6 \%)$ tablets. Each of these types of computers was used for teaching and learning purposes. These results suggest that SQU enjoyed a high availability of ICT infrastructure in terms of hardware, as well as adequate computers and computer labs for educational purposes. Therefore, this result supports the idea of insuring the availability of technology infrastructure prior to integration and for better use of ICT integration into HEIs [7], [8].

\section{2) ICT facilities and support services}

The ICT facilities and support services available for educational use in HEIs represent another useful indicator of hardware accessibility and functionality [18]. The researchers considered the most up-to-date types of computing facilities and support services, including the provision of different forms of computers (workstations, projectors, printers, scanners, whiteboards, etc.) at different locations (offices, classrooms, teaching labs, research labs, etc.). The technicians at different colleges and units were asked to report all computing facilities and support services for SQU students, staff and visitors for teaching and learning purposes.

The data collected from the SIS and the colleges' computer technicians yielded that, the most commonly available ICT facilities at SQU were projectors (351), with the majority of the colleges and centres being provided projectors for teaching and learning process. Table III also shows that the majority of the colleges and centres had printers (213) for instructional purposes. Few colleges at SQU had interactive whiteboards (19), scanners (13) or webcam digital cameras (14) for instructional purposes. The results also show that a very low availability of devices for mentally and physically disabled students in the college sample, with only one college at SQU enjoying five devices with support services. The interview with the CIS showed that, all teaching classrooms and computer labs at SQU were equipped with, at a minimum, a computer for instructors' use, broadband Internet access with adequate bandwidth and a fixed data projector and screen for presentations.

Moreover, the interviews with the CIS also showed that all IT services at SQU (e.g., ICT infrastructure, facilities and support services) were provided and controlled by the CIS. All computer machines at SQU's colleges and centres were loaded with the software solutions necessary for business needs; were kept up-to-date with the latest operating systems (Win 7, 32 Bit and Win 10, 64 Bit) and anti-virus solutions; and were always connected to the Internet. The results also found that there were approximately 45 computer technicians and only two instructional developers in all SQU colleges and centres. The interviews also showed that all users at SQU received technical support for computing-related issues, either directly from CIS or from technicians at SQU's different colleges and centres. This support was given via different channels, including visits to the CIS service desk, phone calls and electronic services.

In addition, the interviews with the CET staff showed that the CET provides technical support to help e-learning system users with such issues as logging in, enrolling in courses, creating new e-templates, adding teachers to courses and managing the front end of the system in general. Further, CET offers training sessions to teach faculty how to use the system. Consequently, the availability and successful development of ICT infrastructure in terms of hardware, software and facilities supports the integration of ICT technologies into teaching and learning processes. These results are aligned with the view of [8] who viewed that the availability of technical support is one of the major opportunities for enabling effective technology integration in teaching and learning.

\section{B. What Professional Development Programmes Are Provided to Help Faculty Members Integrate ICT into Teaching?}

To answer this question, we interviewed CET staff and distributed a questionnaire to faculty members. The head of the Teaching and Learning Department at CET (Salim Jaber AL-Waili) was asked to determine the types of support the CET provided faculty members to help them integrate ICT into teaching and learning. The results show that the CET offers continuous staff development and training sessions to help faculty use ICT (e.g., the e-learning management system, Moodle \& Injazi) in their teaching.

Faculty members were asked to report their participation in training workshops for integrating ICT into teaching.

Results showed that $45.5 \%$ of the respondents had participated in Introductory courses for Internet use and general applications, while $54.5 \%$ of the respondents had not attended these professional development workshops. Results also show that less than $30 \%$ of respondents had participated in all professional development workshops and activities listed in items 2 through 7 . Referring to all items (1 through 7 ), an average of $30.1 \%$ of respondents had not attended the professional development workshops, but wanted to attend if 
available, whereas an average of $40.9 \%$ of respondents had not attended the professional development workshops and did not wish to attend, indicating a lack of interest in and a negative attitude towards integrating ICT into their teaching and learning at SQU. Although there were systematic approaches for continuous staff development at SQU, faculty staff at all colleges need more encouragements to attend the teacher training programmes to support effective technology integration. This result is contradicted by the result conducted by [8] who found that staff development was a major challenge for effective technology integration in Lesoth's universities.

Results of the study also showed that limited financial resources, limited investment in new technology, lack of systematic and sustainable approaches for staff development to support effective technology integration were some of the major challenges faced.

\section{To What Extent Are Faculty Members Integrating ICT Inside and Outside the Classroom?}

To answer the fifth research question, "To what extent are faculty members integrating ICT inside and outside the classroom?", the respondents were asked whether they used ICT tools for teaching preparation processes, presentation, learning support and/or assessment.

Because this study used a descriptive quantitative approach, which uses statistical and numerical data to investigate SQU faculty members' integration of ICT in teaching, we used the following category scales to explain the results:

1) The range from 1.00 to 2.50 refers to a low degree of integration of ICT into teaching.

2) The range from 2.51 to 3.50 refers to a medium degree of integration of ICT into teaching.

3) The range from 3.51 to 5.00 refers to a high degree of integration of ICT into teaching.

Table III presents the mean scores, standard deviations and ranks of faculty members' use of ICT in preparation processes.

TABLE III: DESCRIPTIVE STATISTICS OF FACULTY MEMBERS' ICT INTEGRATION INTO TEACHING

\begin{tabular}{clccc}
\hline \hline Rank & $\begin{array}{l}\text { Activities for integrating ICT into } \\
\text { teaching }\end{array}$ & $N$ & Mean & $S D$ \\
\hline 1 & a. Using ICT for preparation. & 220 & 3.55 & .79 \\
4 & b. Using ICT for presentation. & 220 & 2.42 & .72 \\
2 & c. Using ICT for learning support. & 220 & 3.42 & 1.06 \\
3 & d. Using ICT for assessment and & 220 & 3.41 & .88 \\
& feedback. & 220 & 2.99 & .69 \\
$\quad$ Total
\end{tabular}

Table III shows that, for all activities faculty members used to integrate ICT into teaching at SQU, the mean score (mean $=2.99)$ fell within the range of 2.51 to 3.50 , indicating that faculty members were integrating ICT into teaching to a medium degree. In addition, the table shows that the highest mean scores were observed for activity (a) using ICT for preparation, with a high mean score (3.55); activity (c) using ICT for learning support, with a medium mean score (3.42); and activity (d) using ICT for assessment, with a medium mean score (3.41). Finally, the lowest mean score of all ICT integration activities was recorded for activity (b) using ICT for presentation (2.42).

The study determined the mean scores, standard deviations and ranks for the items within each ICT integration activity (preparation, presentation, learning support and assessment) as follows:

\section{1) Using ICT tools for preparation}

The respondents were asked whether they used ICT in their preparation processes during the academic year. This section presents the mean scores, standard deviations and ranks of faculty members' use of ICT in preparation. The majority of the respondents used ICT in their preparation processes.

TABLE IV: DESCRIPTIVE STATISTICS AND RANKS OF FACULTY MEMBERS' INTEGRATION OF ICT FOR

\begin{tabular}{cllll}
\hline \hline Rank & ICT integration into teaching & $N$ & Mean & $S D$ \\
\hline 1 & $\begin{array}{l}\text { a. Browse/search the Internet to } \\
\text { collect information to prepare } \\
\text { lectures. }\end{array}$ & 220 & 4.26 & .8619 \\
$\quad \begin{array}{l}\text { b. Prepare presentations for lectures } \\
\text { (e.g., Prezi). }\end{array}$ & 220 & 3.58 & 1.2922 \\
$3 \quad \begin{array}{l}\text { c. Create my own digital learning } \\
\text { materials for students. }\end{array}$ & 220 & 3.69 & 1.1846 \\
$2 \quad \begin{array}{l}\text { d. Prepare exercises and tasks for } \\
\text { students. }\end{array}$ & 220 & 3.81 & 1.0008 \\
$\quad \begin{array}{l}\text { e. Post homework for students on the } \\
\text { university LMS (e.g., Moodle) }\end{array}$ & 220 & 3.26 & 1.3627 \\
$6 \quad \begin{array}{l}\text { f. Evaluate digital learning } \\
\text { resources in the subject(s) I teach. }\end{array}$ & 220 & 2.72 & 1.2679 \\
$\quad$ Total & 220 & 3.55 & 0.79 \\
\hline \hline
\end{tabular}

Table IV shows that the mean scores for individual statements ranged from 2.72 to 4.2 , with an overall mean response of 3.55 , indicating that SQU faculty members believe that they integrate ICT into their preparation processes to a medium degree.

More specifically, Table IV shows that four out of five statements had high mean scores ranging between 3.58 and 4.26. These three statements concerning integrating ICT into teaching for preparation purposes were: (a) browse/search the Internet to collect information to prepare lectures (4.26); (d) prepare exercises and tasks for students (3.81); (c) create my own digital learning materials for students (3.69); and (b) prepare presentations for lectures (3.58). The results also showed that only two statements had medium mean scores: post homework for students on the university LMS (e.g., Moodle) (3.26) and evaluate digital learning resources in the subject(s) I teach (2.72). These results suggest that the faculty members integrated ICT tools for content preparation to a medium degree.

\section{2) Using ICT tools for presentation}

Table V shows the descriptive statistics for each of the 18 statements on integrating ICT tools to present information to students. The mean scores for individual statements ranged from 1.64 to 4.32 , with an overall mean response of 2.42.

More specifically, Table V shows that the most ICT tools most commonly used by faculty members to present content to the students were: (a) MS Office applications (4.33) and (i) e-mail communication with students for instruction (4.14). The results also show that only 4 of the 18 ICT tools faculty members used for content presentation had a medium mean score. These were: (d) educational videos from YouTube (3.35); (c) data show (2.99); (q) learning management 
systems (e.g., hosted by Moodle; 2.95); and (e) educational audio (2.45). On the other hand, the results show that only a few teachers used ICT tools to present information. As indicated in the table, 12 of the 18 ICT tools had mean scores less than 2.51. These were: (h) social media networks (e.g., Facebook, Twitter; 2.33); (n) clouds (e.g., Google Drive, Dropbox; 2.21); (j) listservs or online discussion forums (2.11); (f) interactive simulations (2.11); (b) interactive boards (2.08); (o) synchronous interactive presentations (e.g. Prezi) (1.98); (l) blogs (1.84); (k) Wiki pages (1.81); (g) e-portfolio (1.79); (p) course websites by authoring programmes (e.g., Wix; 1.67); (r) course management systems (e.g., hosted by WiziQ, Schoology; 1.66); and (m) online video conferencing (1.46). These results indicate that SQU faculty members believe that they integrate ICT tools into presentations to a low degree.

TABLE V: DESCRIPTIVE STATISTICS FOR FACULTY MEMBERS INTEGRATING

\begin{tabular}{|c|c|c|c|c|}
\hline Rank & $\begin{array}{l}\text { I use and integrate the } \\
\text { following ICT tools to } \\
\text { present information: }\end{array}$ & $\overline{N N}$ & Mean & $S D$ \\
\hline 1 & $\begin{array}{l}\text { a. MS Office applications } \\
\text { (e.g., Word, PowerPoint, } \\
\text { Excel, Access) }\end{array}$ & 220 & 4.33 & .92 \\
\hline 11 & b. Interactive boards & 220 & 2.08 & 1.27 \\
\hline 4 & $\begin{array}{l}\text { c. Data display tools (Data } \\
\text { show) }\end{array}$ & 220 & 2.99 & 1.59 \\
\hline 3 & $\begin{array}{l}\text { d. Educational videos (from } \\
\text { YouTube) }\end{array}$ & 220 & 3.35 & 1.19 \\
\hline 6 & e. Educational audio & 220 & 2.54 & 1.36 \\
\hline 10 & f. Interactive simulation & 220 & 2.11 & 1.14 \\
\hline 15 & g. E-portfolio & 220 & 1.79 & 1.11 \\
\hline 7 & $\begin{array}{l}\text { h. Social media networks } \\
\text { (e.g., Facebook, Twitter) }\end{array}$ & 220 & 2.33 & 1.46 \\
\hline 2 & $\begin{array}{l}\text { i. E-mail communication } \\
\text { with students for instruction }\end{array}$ & 220 & 4.14 & 1.17 \\
\hline 9 & $\begin{array}{l}\text { j. Listserv or online } \\
\text { discussion forum }\end{array}$ & 220 & 2.11 & 1.18 \\
\hline 14 & k. Blogs & 220 & 1.84 & 1.02 \\
\hline 13 & 1. Wiki pages & 220 & 1.81 & 1.03 \\
\hline 18 & $\begin{array}{l}\text { m. Online video } \\
\text { conferencing }\end{array}$ & 220 & 1.64 & .97 \\
\hline 8 & $\begin{array}{l}\text { n. Clouds (e.g., Google } \\
\text { Drive, Dropbox) }\end{array}$ & 220 & 2.21 & 1.24 \\
\hline 12 & $\begin{array}{l}\text { o. Synchronous interactive } \\
\text { presentations (e.g., Prezi) }\end{array}$ & 220 & 1.98 & 1.22 \\
\hline 16 & $\begin{array}{l}\text { p. Course websites by } \\
\text { authoring programmes (e.g., } \\
\text { Wix) }\end{array}$ & 220 & 1.67 & 1.10 \\
\hline 5 & $\begin{array}{l}\text { q. Learning management } \\
\text { systems (e.g., hosted by } \\
\text { Moodle) }\end{array}$ & 220 & 2.95 & 1.54 \\
\hline 17 & $\begin{array}{l}\text { r. Course management } \\
\text { systems (e.g., hosted by } \\
\text { WiziQ, Schoology) }\end{array}$ & 220 & 1.66 & 1.00 \\
\hline & Total & 220 & 2.42 & .72 \\
\hline
\end{tabular}

\section{3) Using ICT tools for learning support}

Table VI shows the descriptive statistics for each of the five statements concerning integrating ICT tools for learning support. The mean scores for the individual statements ranged from 3.29 to 3.62 , with an overall mean response of 3.42 .

Table VI shows that the mean scores for individual statements ranged from 3.29 to 3.62 , with an overall mean response of 3.42, indicating that SQU faculty members believed that they integrated ICT tools for learning support to a medium degree. Moreover, as illustrated in the table, only one of the five statements had a high mean score: (a) learner motivation (3.62). The remaining four statements concerning integrating ICT for learning support recorded medium mean scores, as follows: (b) development of problem-solving skills in students (4.26); (c) development of self-directed learning skills in students (3.36); (e) development of communication skills in students (3.36); and (d) Development of collaborative skills in students (3.29).

TABLE VI: DESCRIPTIVE STATISTICS FOR FACULTY MEMBERS INTEGRATING ICT INTO TEACHING FOR LEARNING SUPPORT

\begin{tabular}{clccc}
\hline \hline Rank & I use ICT to support: & $N$ & Mean & $S D$ \\
\hline 1 & $\begin{array}{l}\text { a. Learner motivation } \\
\text { b. Development of } \\
\text { problem-solving skills in }\end{array}$ & 220 & 3.62 & 1.178 \\
& $\begin{array}{l}\text { students } \\
\text { c. Development of self-directed } \\
\text { learning skills in students }\end{array}$ & 220 & 3.49 & 1.14 \\
4 & $\begin{array}{l}\text { d. Development of } \\
\text { collaborative skills in students } \\
\text { e. Development of } \\
\text { communication skills in students }\end{array}$ & 220 & 3.29 & 1.18 \\
& Total & 220 & 3.36 & 1.23 \\
\hline \hline
\end{tabular}

\section{4) Using ICT tools for assessment and feedback}

Table VII shows the descriptive statistics for each of the five statements concerning integrating ICT tools for assessment and feedback. The mean scores for individual statements ranged from 2.78 to 4.50 , with an overall mean response of 3.42 .

TABLE VII: DESCRIPTIVE STATISTICS FOR FACULTY MEMBER INTEGRATING ICT IN TEACHING FOR ASSESSMENT AND FEEDBACK.

\begin{tabular}{|c|c|c|c|c|}
\hline Rank & I use ICT to support: & $\bar{N}$ & Mean & $\overline{S D}$ \\
\hline 3 & $\begin{array}{l}\text { a. Preparation of tests or } \\
\text { exams }\end{array}$ & 220 & 3.83 & 1.26 \\
\hline 2 & b. Written tasks/exercises & 220 & 3.88 & 1.13 \\
\hline 4 & $\begin{array}{l}\text { c. Individual audio/visual } \\
\text { presentations }\end{array}$ & 220 & 3.41 & 1.34 \\
\hline 6 & $\begin{array}{l}\text { d. Group presentations } \\
\text { (oral/written) }\end{array}$ & 220 & 3.37 & 1.34 \\
\hline 5 & $\begin{array}{l}\text { e. Project reports and/or } \\
\text { (multimedia) products }\end{array}$ & 220 & 3.40 & 1.29 \\
\hline 10 & $\begin{array}{l}\text { f. Assessment of group } \\
\text { performance on } \\
\text { collaborative tasks }\end{array}$ & 220 & 3.00 & 1.31 \\
\hline 9 & $\begin{array}{l}\text { g. Posting assessment } \\
\text { results }\end{array}$ & 220 & 3.01 & 1.43 \\
\hline 8 & $\begin{array}{l}\text { h. Analysing students' } \\
\text { results }\end{array}$ & 220 & 3.10 & 1.40 \\
\hline 1 & i. University attendance & 220 & 4.50 & .94 \\
\hline 7 & $\begin{array}{l}\text { j. Providing immediate } \\
\text { feedback to individuals } \\
\text { and/or small groups of } \\
\text { learners }\end{array}$ & 220 & 3.25 & 1.24 \\
\hline \multirow[t]{2}{*}{11} & $\begin{array}{l}\text { k. Providing delayed } \\
\text { feedback }\end{array}$ & 220 & 2.78 & 1.25 \\
\hline & Total & 220 & 3.41 & .88 \\
\hline
\end{tabular}

Table VII shows that the mean scores for individual statements ranged from 2.78 to 4.50 , with an overall mean response of 3.41, indicating that the SQU faculty members believe that they integrated ICT tools for assessment and feedback to a medium degree. Moreover, as illustrated in the 
table, only 3 of the 11 statements had high mean scores. These were: (j) university attendance (4.50); (b) written tasks/exercises (3.88); and (a) preparation of tests or exams (3.83). The results also show that about eight statements had medium mean scores. These were: (c) individual audio/visual presentations $(3.41)$; (e) project reports and/or (multimedia) products (3.40); (d) group presentations (oral/written) (3.37); (j) providing immediate feedback to individuals and/or small groups of learners (3.25); (h) analysing students' results (3.10); (g) posting assessment results (3.01); (f) assessment of group performance on collaborative tasks (3.00); and (k) providing delayed feedback (2.78).

\section{Are There Any Differences in ICT Integration According to College, Gender, Experience, or Rank?}

To answer question six — "Are there any differences in ICT integration according to college, gender, experience, or academic rank?" - An independent sample t-test was used to compare faculty members' integration of ICT by gender. To test differences in the means of the faculty members' ICT integration by experience and rank, an ANOVA test was used.

TABLE VIII: T-TEST SCORES FOR DIFFERENCES IN MEANS OF INTEGRATING ICT ACCORDING TO

\begin{tabular}{clcccccc}
\hline Gender & Groups & $n$ & Mean & SD & Df & $t$ & $\begin{array}{c}\text { Sig. } \\
\text { (2-tailed) }\end{array}$ \\
\cline { 2 - 8 } & Male & 179 & 2.95 & .70 & 218 & 1.688 & .093 \\
& Female & 41 & 3.15 & .6 & & & \\
\hline
\end{tabular}

As seen in Table VIII, an independent-sample t-test was conducted to compare faculty members' means of integrating ICT according to gender. There were no significant differences in the means for males and females concerning technology integration $(t$-value $=-1.688, d f=218$, sig. $=.093)$. This result could be attributed to the fact that SQU provided all faculty members in the science and humanities colleges with training workshops on the importance of ICT and methods to incorporate technology in their lectures, which may have influenced their ICT use and practices.

To answer question six in terms of the experience variable, an ANOVA test was used. The means and standard deviations for years of experience are described below.

TABLE IX: MEANS AND STANDARd DEVIATIONS FOR FACUlTy MEMBERS' INTEGRATION OF ICT BY EXPERIENCE

\begin{tabular}{llll}
\multicolumn{4}{c}{ INTEGRATION OF ICT BY EXPERIENCE } \\
\hline \hline Experience & $N$ & Mean & $S D$ \\
\hline 5 years or less & 8 & 2.84 & .93 \\
6 to 10 years & 45 & 3.03 & .55 \\
11 to 20 years & 86 & 3.05 & .69 \\
More than 20 years & 81 & 2.91 & .75 \\
Total & 220 & 2.99 & .69 \\
\hline \hline
\end{tabular}

It is clear from Table IX that faculty members with 6 to 10 and 11 to 20 years of experience had the highest mean scores ( $M=3.03$ and 3.05 , respectively). To check for any significant differences, further analysis was conducted using an ANOVA test. The results are presented in Table X.

Table X shows the ANOVA test comparing the means of years of teaching experience for respondents who completed the survey. No significant difference among the four groups was found for technology integration based on teaching experience $(F=.692, d f=3$, sig. $=.558>.05)$. This result could be explained by considering that teachers' years of experience did not change their use of ICT technology[19]. Moreover, all faculty members at SQU were provided ICT training to incorporate technology into teaching, which may have equalised their levels of experience in integrating technology into teaching.

TABLE X: ANOVA FOR THE MEAN DIFFERENCE IN ICT INTEGRATION WITH RESPECT TO EXPERIENCE

\begin{tabular}{lccccc}
\hline \hline & $\begin{array}{c}\text { Sum of } \\
\text { Squares }\end{array}$ & $d f$ & $\begin{array}{c}\text { Mean } \\
\text { Square }\end{array}$ & $F$ & Sig. \\
\hline $\begin{array}{l}\text { Between } \\
\text { groups }\end{array}$ & 1.006 & 3 & .335 & .692 & .558 \\
Within groups & 104.712 & 216 & .485 & & \\
Total & 105.718 & 219 & & & \\
\hline \hline
\end{tabular}

An ANOVA test was also used to answer question six in terms of the academic rank variable. The means and standard deviations for the ranks are described below.

TABLE XI: MEANS AND STANDARd DEVIATIONS FOR FACUlty MEMBERS' INTEGRATION OF ICT BY ACADEMIC RANK

\begin{tabular}{llll}
\hline \hline Academic rank & $N$ & Mean & $S D$ \\
\hline Lecturer & 20 & 2.99 & .79645 \\
Assistant professor & 125 & 3.04 & .66602 \\
Associate professor & 56 & 2.96 & .70264 \\
Professor & 19 & 2.74 & .74365 \\
Total & 220 & 2.99 & .69479 \\
\hline \hline
\end{tabular}

It is clear from Table XI that faculty members with the "assistant professor" rank had the highest mean scores $(M=$ 3.04). To check for any significant differences, further analysis was conducted using an ANOVA test. The results are presented in Table XII.

TABLE XII: ANOVA FOR THE MEAN DIFFERENCES IN ICT INTEGRATION WITH RESPECT TO ACADEMIC RANK

\begin{tabular}{lccccc}
\hline \hline & $\begin{array}{l}\text { Sum of } \\
\text { squares }\end{array}$ & $D f$ & $\begin{array}{c}\text { Mean } \\
\text { Square }\end{array}$ & $F$ & Sig. \\
\hline $\begin{array}{l}\text { Between } \\
\text { groups }\end{array}$ & 1.553 & 3 & .518 & 1.074 & .36 \\
Within groups & 104.165 & 216 & .482 & & \\
Total & 105.718 & 219 & & & \\
\hline \hline
\end{tabular}

Table XII shows the ANOVA test comparing the means of academic rank for respondents who completed the survey. No significant difference among the four groups was found for technology integration based on academic rank $(F=$ 1.074 , with $d f=3$, sig. $=.36>.05)$. This result could be justified by the fact that most faculty members at SQU were trained to use technology in teaching, which may have equalised their levels of experience in integrating technology into teaching.

\section{CONCLUSION}

Higher education systems are under increasing pressure to integrate ICT in order to teach students the knowledge and skills needed for the future knowledge society. They need to integrate ICT into teaching and learning as a medium through 
which a variety of approaches and pedagogical philosophies may be implemented. However, integrating ICT as a tool is more complicated in that it demands specific skills from instructors (technically and pedagogically), along with their positive beliefs about ICT integration. This study explored the current status of using ICT in teaching and learning at SQU. Based on the findings, we recommend future plans to motivate change and coordinate disparate efforts to advance overall educational goals for the educational process at SQU. Though the study sample was limited to 220 faculty members and four staff from the CET and CIS, this study provides a good picture of the availability of ICT (infrastructure, support services and resources) at SQU. The study also provides a good picture of faculty members' views pertaining to the main ICT infrastructure accessible for teaching and learning, professional development programmes and integrating ICT into teaching process.

In general, the research study concluded that, although there was adequate hardware in terms of computers and computer labs for educational purposes, there were few digital learning tools for integrating technology into teaching (e.g., digital cameras or camcorders, e-readers, computer laboratory student response systems and interactive whiteboards). In addition, SQU provided a series of professional development workshops related to using ICT in teaching through the CET, SIC and the Center for Excellence in Teaching and Learning, but few faculty members attended the workshops. Therefore, the findings show that professional development workshops are important for encouraging instructors to practice and share ideas about new ICT technologies and how to integrate them into teaching.

The degree of ICT integration in teaching is currently at a medium degree, according to faculty members' points of view. Therefore, faculty members need to learn to integrate ICT tools into their classroom activities (e.g., preparation, presentation, learning support and assessment and feedback) through practicing and sharing best teaching practices. T-tests compressions for gender revealed no significant differences in the means of males and females with respect to ICT integration. Moreover, an ANOVA comparing the means of years of teaching experience and rank showed no significant differences in either variable.

\section{IMPLICATIONS}

This study investigated some factors that affect ICT integration into teaching and learning at SQU. It has showed also an understanding of how ICT could be used in education in the specific context (e.g., preparation, presentation, learning support and assessment \& feedback). New practices would have implications for policy makers in the development of new ICT policy and deployment of resources to the university. ICT policy should focus on utilising existing ICT infrastructures in all colleges and centers.

SQU could play a vital role in delivering ICT-based education to students. Given the importance of ICT integration in teaching and learning, it is recommended that SQU should recognise and acknowledge the faculty members' role in ICT integration. Therefore, it should provide ways to support faculty members in developing their
ICT skills and knowledge and increasing capability in performing their role.

\section{RECOMMENDATIONS}

To create an environment of effective ICT integration at SQU, policymakers should focus on eliminating the barriers highlighted by this research study. Based on the findings and discussions presented here, we offer policymakers at SQU the following recommendations for furthering the implementation of ICT in education.

- SQU must make the necessary technology available to lecturers and students to allow them to use it meaningfully in teaching and learning.

- SQU should prepare and implement technology plans for implementing ICTs in each college.

- Both the quantity and quality of professional development programmes relating to ICTs for faculty members should be improved.

- Every college at SQU should have at least one free laboratory available to students.

- University investments in teacher training programmes and support services for instructional technologies should be prioritised to integrate ICT into teaching and learning processes.

- Teachers' ongoing training in ICT skills and ICT pedagogical knowledge should be supported.

- Faculty members who integrate ICT elements into their teaching should be encouraged and supported.

- Lecturers, who are greatly influenced by time and incentives, need to be granted space within their busy schedules to develop ICT-supported modules and programmes.

\section{Recommendations for Further Research}

Further studies should seek to understand and assess the nature of ICT integration, taking into account such factors as the planning process, the maintenance of technology equipment, and the budget for technology integration.

A comprehensive quantitative study of students' perceptions towards using ICT in teaching and learning at SQU during the emergency eLearning plan could be explored.

\section{CONFLICT OF INTEREST}

The authors do not have any conflicts of interest to report.

\section{AUTHOR CONTRIBUTIONS}

Dr. Ahmed, A. conducted the data collection and processing, conducted the data analysis and interpretation and co-wrote the paper. Dr. Abdel Raheem, A. conducted the interpretation, and co-wrote the paper.

\section{ACKNOWLEDGMENT}

This research was supported by Sultan Qaboos University (SQU) [Internal Grant, Project No:IG/EDU/TECH/17/01]. We thank our colleagues from all colleges in SQU, Center for Information Technology and Center of Educational Technology who provided us with the data required for this 
project. We thank Fatma Aljahwari, our research assistant, for assistance with the research tools, data collection and analysis.

We would further like to show our gratitude to the assistant dean of post-graduate and research, Professor Adnan AL Apid, SQU, for support and assistance with the project's administrative issues. Finally, we are immensely grateful to the editing company Scribendi for its editing and proofreading of this manuscript.

\section{REFERENCES}

[1] C. -H. Chen, "Why do teachers not practice what they believe regarding technology integration?" The Journal of Educational Research, vol. 102, no.1, pp. 65-75, 2008.

[2] J. M. Clausen, "Beginning teachers' technology use: First-year teacher development and the institutional context's affect on new teachers' instructional technology use with students," Journal of Research on Technology in Education, vol. 39, no. 3, pp. 245-261, 2007.

[3] C. P. Lim and C. S. Chai, "Teachers' pedagogical beliefs and their planning and conduct of computer-mediated classroom lessons," British Journal of Educational Technology, vol. 39, no. 5, pp. 807-828, 2008.

[4] J. Tondeur, M. Valcke, and J. Braak, "A multidimensional approach to determinants of computer use in primary education: Teacher and school characteristics," Journal of Computer Assisted Learning, vol. 24, pp. $494-506,2008$.

[5] E. Neyland, "Integrating online learning in NSW secondary schools: Three schools' perspectives on ICT adoption," Australasian Journal of Educational Technology, vol. 27, no. 1, 2011.

[6] M. Mbodila, T. Jones, and K. Muhandji, "Integration of ICT in education: Key challenges," International Journal of Emerging Technology and Advanced Engineering, vol. 3, no. 11, pp. 515-520, 2013.

[7] J. Peeraer and P. V. Petegem, "Integration or transformation? Looking in the future of information and communication technology in education in Vietnam," Evaluation and Program Planning, vol. 48, pp. $47-56,2015$.

[8] M. Turugare and N. Rudhumbu, "Integrating technology in teaching and learning in universities in Lesotho: opportunities and challenges," Educ Inf Technol., 2020.

[9] T. Rubang-Doctor et al., "Factors influencing the adoption and integration of ICT in teaching among foreign teachers in Thailand," I-Manager's Journal of Educational Technology, vol. 16, no. 1, pp. $33-50,2019$.

[10] N. Y. Asabere and A. M. Ahmed, "Towards enhancing quality in education through information and communication technologies (ICTs) in higher educational institutions (HEIs)," International Journal of Computer Applications, vol. 62, no. 8, pp. 10-18, 2013.

[11] G. Kituyi and I. Tusubira, "A framework for the integration of e-learning in higher education institutions in developing countries,"
International Journal of Education and Development using Information and Communication Technology (IJEDICT), vol. 9, no. 2, pp. 19-36, 2013

[12] S. M. Abdelhalim, "An interpretive inquiry into the integration of the information and communication technology tools in TEFL at Egyptian universities," Journal of Research in Curriculum, in struction and Educational Technology (JRCIET), vol. 2, no. 4, pp. 145-173, 2016.

[13] A. S. Al-Aufi and C. Fulton, "Use of social networking tools for informal scholarly communication in humanities and social sciences disciplines," Procedia - Social and Behavioral Sciences, vol. 147, pp. 436-445, 2014.

[14] H. A. Shihi, B. Gattoufi, and S. Gulvady, "Introducing MOOCs to universities in Oman - policies and regulations- CAS perspective," 2015.

[15] K. Ramachandran et al., "Technology and English language education: A case study of Caledonian College of Engineering," The Journal of Teaching English for Specific and Academic Purposes, vol. 4, no. 1, pp. 9-22, 2016.

[16] M. Mafuraga and M. Moremi, "Integrating information and communication technology in English language teaching: A case study of selected Junior Secondary Schools in Botswana," International Journal of Education and Development Using Information and Communication Technology (IJEDICT), vol. 13, no. 1, pp. 142-152, 2017.

[17] A. Ahmed, "The implementation of ICT strategy at Sudanese Secondary Schools," Ph.D. thesis in computer integrated education, Sudan University of Science and Technology, SUDAN, 2010.

[18] A. Ahmed, "A preliminary study of ICT's infrastructure and pedagogical practices for technology integration in Sudanese Secondary schools," International Journal of Instructional Technology and Distance Learning, vol. 12, no. 7, pp. 37-54, 2015.

[19] Y. Lam, "Technophilia vs. technophobia: A preliminary look at why second-language teachers do or do not use technology in their classrooms," Canadian Modern Language Review, vol. 56, no. 3, pp. 390-420, 2000.

Copyright $\odot 2020$ by the authors. This is an open access article distributed under the Creative Commons Attribution License which permits unrestricted use, distribution, and reproduction in any medium, provided the original work is properly cited (CC BY 4.0).

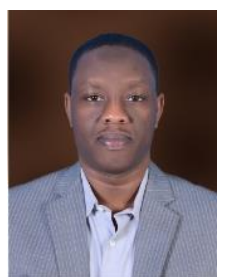

Abdelrahman Ahmed is an assistant professor of educational technology in the Department of Teaching and Learning Technologies at Sultan Qaboos University (SQU) in Oman. He obtained his Ph.D. from Sudan University of Science and Technology (Sudan) with association of the University of Pretoria (South Africa). He published many research studies at recognized refereed journals. He presented many papers in International Conferences. His current areas of research include technology integration, social media, mobile learning, e-learning, distance education, and use of web 2.0 technologies in education. 